\title{
sciforum
}

Conference Proceedings Paper

\section{Fine, Coarse and Fine-Coarse Particle Flotation in Mineral Processing With A Particular Focus On The Technological Assessments}

\author{
Ahmad Hassanzadeh ${ }^{1, *}$, Mehdi Safari ${ }^{2}$ and Duong Huu Hoang ${ }^{3}$ \\ 1 Independent Scholar, Am Apostelhof 7A, 50226 Frechen, North Rhine-Westphalia, Germany; \\ a.hassanzadeh@gmx.de \\ 2 Centre for Minerals Research, Department of Chemical Engineering, University of Cape Town, Private Bag \\ Rondebosch, Cape Town 7700, South Africa; saffari_mehdi@yahoo.com \\ 3 Maelgwyn Mineral Services Ltd, Ty Maelgwyn, 1A Gower Road, Cathays, Cardiff, CF24 4PA, United \\ Kingdom; dhoang@maelgwyn.com \\ * Correspondence: a.hassanzadeh@gmx.de; Tel.: +4917620666711 (A.H.)
}

Received: date; Accepted: date; Published: date

\begin{abstract}
After more than a century applying flotation to the mining industry, two completely different strategies have been introduced for processing purposes. One is the classical approach viz. grinding the ores to certain extend and floating them via conventional mechanical and recently pneumatic cells e.g. Jameson and Imhoflot ${ }^{\mathrm{TM}}$ cells. This strategy continuous because mines face up to declining cut-off grades, complex and poly-mineralized ores, and they require to achieve an acceptable degree of mineral liberation. The other school of mind deals with the coarse particle processes mainly owing to the low energy needs, that includes flash, fluidized bed and HydroFloat ${ }^{\mathrm{TM}}$ cells. The third and newest system proposes processing both fine and coarse sizes by flotation machines like oscillating grid flotation (OGC) and Reflux flotation cells. The present paper endeavours to critically evaluate these concepts from several points of view including existing technological elaborations, water and energy usages, kinetics and circuit design. Brief introduction of advanced technologies, along with their applications, were presented. It was revealed that the incorporation of coarse grinding apparatuses, mineralogical techniques together with the technologically applicable classification systems and adapted simulator tools are urgent needs for coarse flotation as the future requirements for mining industries. However, fine particle flotation may remain as the main focus of re-processing tailings dams.
\end{abstract}

Keywords: Flotation cells; fine and coarse particles; technological development; flotation kinetics; HydroFloat ${ }^{\mathrm{TM}}$ cells

\section{Introduction}

Froth flotation was undoubtedly the most innovative and mining saver in ore dressing in the 19th century [1]. Nevertheless, it did not last long that scientists recognized its limitations for extremely fine $(<20 \mu \mathrm{m})$ and coarse particles $(>150 \mu \mathrm{m})$ which have been remained as a long-standing unsolved issue in the mineral processing field [2]. From the early 20th century, many active industries applied the simplest solution to tackle this issue by increasing flotation cell size [3] with paying less attention to designing an efficient cell. This strategy has been a matter of argument over many years, which the present paper points this out by categorizing it into mainly two subdivision groups. 
Generally speaking, three key points force the mining industries to coarse particle treatment containing I) drastic environmental consequences of wet tailings dams and acid mining drainage (AMD), II) losing precious materials in the coarse fraction sizes and III) enormous energy consumption (i.e., $2-4 \%$ global electricity usage) in comminution stages with less than $2 \%$ efficiency [4]. Although these concepts are well established, only a few technological developments have been appeared in mineral processing industries over the last decades. Microwave technology [5-6], high pressure grinding rolls (HPGR), and pneumatic type flotation cells are the major illustrations in this regard. The most recent industrial examples might be the commercialized rapid microwave and Nova Cell ${ }^{\mathrm{TM}}$. The former is the microwave (MW)-assisted grinding [7] which leads to a remarkable increase in material's grindability, improvement of mineral liberation degree and reduction of the comminution energy over $30 \%$. The latter is a developed flotation machine (Nova Cell ${ }^{\mathrm{TM}}$ ) shows saving in operating costs of grinding energy and media by $40 \%$ and $12 \%$ decrease in overall site operating cost [8].

In an industrial scale, up- and down-stream operating units (e.g. de-watering, grinding and classification) inevitably affect metallurgical responses of a flotation process. Thus, the efficiency of either coarse or fine particle treatment systems is inherently coupled with the performance of these units. For example, processing of rare earth elements (REEs) embedded in carbonate, fluorocarbonate, phosphate and fluorite deposits faces with massive challenges concerning their extremely low grades which leads to being ground finely for achieving a desirable liberation degree [9]. Poor recovery of fine particles is mainly related to the low frequency of collision between particles and bubbles $\left(Z_{\mathrm{pb}}\right)$ [10-14], high specific surface area, high surface energy and most importantly low particle inertial force [15]. Technically speaking, to improve fine particles recovery in flotation, one must whether increase the particle size or decrease the bubble diameter. In this regard, the particle sizes can be enlarged by flocculants, while the small bubbles can be generated via dissolved-air flotation, induced-air flotation, hydrodynamic cavitation, electro-flotation and microbubble generators. The most common belief is creating an intense turbulent environment to increase particle-bubble collision efficiency $\left(\mathrm{E}_{\mathrm{c}}\right)$, which is an extremely energy-consuming process [16-18]. Other than those, it was indicated at the OK Tedi plant that sulphidization by NaHS could improve copper recovery of fine particles $(<20 \mu \mathrm{m})$ up to $3.4 \%$ [19]. Shear flocculation or high-intensity conditioning (HIC) is another technique used to upgrade the recovery of fines [20]. Mechanical vibration and the acoustic wave pre-treatments is also reported as a promising approach to enhance the recovery of fine fraction sizes up to ca. $3.5 \%$ by a cleaning effect on the surface of the minerals and generation of heterogeneous nucleation of microbubbles on the particle surfaces [21-22].

Some researchers worked on overcoming the challenges of fine and coarse particle flotation systems. Jameson [23] presented theoretical backgrounds regarding the main difficulties in recovering ultra-fine and coarse particles. He developed Concorde ${ }^{\mathrm{TM}}$ flotation cell and applied fluidization principles to upgrade recovery of ultra-fine (nickel sulphide and platinum ores) and coarse particles (galena) by a factor of ten. Recent advances in FLSmidth Inc. as a pioneer company in flotation processes can be classified into three groups as I) forced-air flotation machines (Dorr-Oliver) designed for recovering fine particles in terms of imposing high energy to these particles concerning their low inertia in tiring down the water film. II) induced-air flotation cells (Wemco) favourable for recovering coarse particles since these particles can be collected next to the surface and the travel distance to froth from the discharge lip is reasonably short. III) forced-air and induced-air cells (Dorr-Oliver and Wemco) in a circuit with the idea of recovering both fine and coarse sizes using a combination of the two technologies in the same row/bank or different flotation stages [24].

The present paper aims at introducing technological barriers that the froth flotation currently faces up with a particular focus on the identification of challenges and opportunities for treating coarse and fine particles. 


\section{2. Limitation of mineralogical approaches}

Selection of fine or coarse particulate systems strongly requires a precise and appropriate mineralogy characterization approach. Recent developments indicated that X-ray computed micro-tomography $(\mu \mathrm{CT}$ ) and mineral liberation analyzer (MLA) have been extensively utilized to characterize a variety of particle properties in the scope of process mineralogy for coarse and fine particle sizes, respectively [25]. The $\mu \mathrm{CT}$ is a non-invasive $3 \mathrm{D}$ technique that allows to image the distribution of minerals inside a sample while scanning electron microscopy-based methods like MLA and QEMSCAN (quantitative evaluation of materials by scanning electron microscopy (SEM)). It allows for a 2D quantitative analysis of mineral essays by combining backscattering electron (BSE) images with energy-dispersive X-ray spectroscopy (EDS) [26]. The low resolution (tens of microns) and the lack of chemical information have typically limited the application of $\mu \mathrm{CT}$ to identify and analyze fine particles. Nevertheless, it remains unclear how coarse a particle must be to be accurately measured by $\mu$ CT [27].

From industrial perspectives, it is now possible to on-site measure particle characteristics in the range of $1-150 \mathrm{~mm}$ with a voxel resolution of approximately $100 \mu \mathrm{m}$ at the sampling rate of $1 \mathrm{~kg} / \mathrm{min}$ using high-speed X-ray computed tomography (HSXCT). Detailed information concerning the on-site measurements for coal washability, crusher plant products and pebble phosphates case studies can be found elsewhere [28-29]. Also, recent studies have manifested that the MLA and QEMSCAN cannot be applied in-situ and for coarse particle sizes [30]. For fine particles, it unavoidably suffers from a stereological bias along with a statistical dispersion in the light of the number of analyzed particles [31] which results in an overestimation of mineral liberation degrees. Moreover, there are natural uncertainties inherently linked to representativity and sample preparation shortcomings [32]. According to the raised assertions, there is an urgent need to tackle these issues related to either coarse or fine process mineralogies.

\section{Fine or coarse particulate systems}

Elephant curve is an explicit demonstration of the inefficiency of conventional flotation cells for recovering both fine and coarse fractions [33]. Figure 1 schematically illustrates the technological developments for raising either tail (via fine flotation systems, FFS) or trunk (by coarse flotation system, CFS) based on the energy consumptions [34].

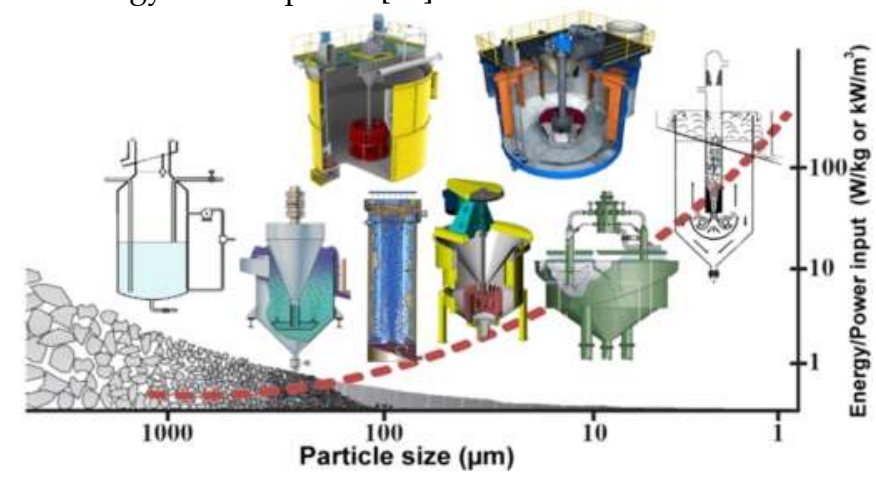

Figure 1. An overview of existing flotation equipment based on energy consumption and particle size

\subsection{Fine Flotation}

In this section, technological and conceptual advances in FFS are briefly introduced. Other developments such as electro-flotation (EF) [35-37], carrier flotation [38] and reactive oily bubble systems [39-41] are not discussed in this paper. In this scope, one can find invaluable information in a manuscript presented by Farokhpay et al. [42]. Furthermore, two devices developed at the University of Newcastle, Australia i.e. Concorde cell ${ }^{\mathrm{TM}}[23,43]$ and the Reflux Flotation Cell (RFC) [44] together with StackCell ${ }^{\mathrm{TM}}$ typically used for treating particles $<150 \mu \mathrm{m}$ (Eriez Manufacturing Co.) [1] are not included in this paper. They will be presented and discussed in details in a future study.

\subsubsection{Pneumatic cells}


Pneumatic flotation technology was originally developed in the 1970s by Bahr et al. [45] at the Technical University of Clausthal (Germany) and Simonis et al. [46] at the Technical University of Berlin (Germany) which the cell was so-called Bahr cell. The first research work was initiated in 1973 while the prototyped model was built up in 1978. It is well documented that the pneumatic flotation is more effective than the conventional cells in terms of recovering fine particles [47]. The pneumatic and traditional flotation cells differ concerning a requirement for compressed air and agitation, which consequences substantial energy saving in pneumatic ones [48]. Most recently, Safari et al. [49] pointed out this by reverse flotation of iron ore utilizing mechanical, oscillating grid and pneumatic cells. They manifested that the pneumatic flotation cell shows the best flotation performance for most operating conditions. Lima et al. [50] addressed the same concept by comparatively analyzing mechanical and pneumatic cells for quartz flotation. Two commonly used pneumatic flotation machines are Jameson ${ }^{\mathrm{TM}}$ and Imhoflot ${ }^{\mathrm{TM}}$ cells discussed as follows.

\subsubsection{Jameson Cell}

There have been about 350 Jameson Cells installed in a variety of coal (especially in Australian coal industry), metalliferous and industrial mineral application worldwide [51-52]. This type of flotation cell was used for upgrading final grade and increasing capacity issues of conventionally operated flotation cleaner circuits [53]. It was initially developed as a low-cost alternative to traditional column flotation cells for recovering fine particles. It was firstly installed at Mount Isa lead-zinc concentrator in 1988 and successfully recovered fine particles $(<12 \mu \mathrm{m})$. Higher lead grade in concentrate $(60 \%)$ was reported compared to the conventional cleaning circuit (51\%). The Jameson Cell was successfully operated in the cleaning stage to treat the porphyry gold-copper ore in Minera Alumbrera Ltd in Argentina resulting in respectively gold and copper recoveries of about $80 \%$ and 90\% for particles finer than $10 \mu \mathrm{m}$ [54].

Technically, the cell works by closing the air inlet at the top of the downcomer while feeding the flotation pulp through the nozzle leads to the high-intensity particle-bubble contacting [55]. The feed is pumped into the downcomer through an orifice plate, and create a high-pressure jet where the plunging jet of liquid shears and entrains air [56]. It results in a rapid contact and collection of particles and bubbles in high mixing velocity and a large interfacial area, which ultimately consequences extremely short residence time. A vital privilege of this type of cell to the traditional mechanical cells is its faster kinetics rate. This relates to the gas holdup in a confined downcomer which is typically far higher than that of a conventional flotation vessel, reaching in some cases up to $60 \%$ [57]. However, the typical mean residence time (MRT) of a mechanical cell circuit is about 4-20 min for a rougher stage, depending on the mineral type and the number of cells in a bank, and up to 30 min for scavengers, while for a flotation column is in the range of 18 to $23 \mathrm{~min}$, depending on the column design [58]. In this scope, Harbort et al. [59] reported a reduction in MRT of a mechanical rougher-scavenger circuit (17.9 $\mathrm{min}$ ) and cleaner-scavenger circuit (30 $\mathrm{min}$ ) down to $7.5 \mathrm{~min}$ and $2.5 \mathrm{~min}$ using Jameson cells with identical flotation performances.

\subsubsection{Imhoflot ${ }^{\mathrm{TM}}$ cell}

The history and development of Imhoflot ${ }^{\mathrm{TM}}$ pneumatic flotation cells are well documented in several technical reports [60-62]. The commercialization began in the early 1980s. From designing perspective, it differs from the conventional cells in that the particle-bubble collision takes place outside of the cell, within the aerator (called as a pipe flotation) [47]. Similar to HydroFloat ${ }^{\mathrm{TM}}$ and column flotation cells, it does not require compressed air and agitation, which provides the opportunity of saving a tremendous amount of energy compared to the traditional mechanical cells. The energy input goes more directly into the particle-bubble collision, rather than energy being used to maintain the pulp in suspension as in mechanical cells. The slurry is pumped with enough fluid energy to produce intensive aspiration of air and rapid dispersion for efficient particle-bubble collision [63]. The method of self-aspiration of Imhoflot ${ }^{\mathrm{TM}}$ flotation is based on the well-known venturi principal. However, the patented design has a complex system of nozzles, impingement plates and gas hold up mechanisms that generates a spectrum of fine bubble size. Maeqwyn Imhoflot ${ }^{\mathrm{TM}}$ flotation cell has three different types, i.e., vertically fed (V-cell), tangentially fed (G-cell) and another type called $\mathrm{H}$-cell, which is similar to the G-cell. This type enables to introduce feed vertically via a separate 
distributor box located at the base of the tank. The design of the Imhoflot ${ }^{\mathrm{TM}}$ cell type depends on the particle size. The V-cell is generally used for the intermediate and coarse particle (i.e. 50-300 $\mu \mathrm{m}$ ) flotation while the residence time is approximately $3 \mathrm{~min}$. Imhoflot ${ }^{\mathrm{TM}} \mathrm{G}$-cell is favoured for very fine to intermediate-sized particles (i.e. $<50 \mu \mathrm{m}$ ) with a very short residence time of approximately $1 \mathrm{~min}$ depending on the particle size, mineral characteristics i.e., mineral hydrophobicity, association, and liberation. The Imhoflot ${ }^{\mathrm{TM}}$ flotation cell including G-cell has been successfully applied to the mineral processing and recycling industries in the last two decades and practically demonstrated its capability in recovering ultra-fines. The application of a three stages Imhoflot G-Cell at a nickel operation plant in Europe showed its ability to recover approximately $30 \% \mathrm{Ni}$ from the final tailings, predominantly in the $<11 \mu \mathrm{m}$ size fraction. Further, a two-stage Imhoflot G-Cell plant was established at a zinc operation to avoid losing fine intergrowth $7 \mu \mathrm{m}$ particles. It recovered ca. $20 \%$ of the zinc from the final cleaner tailings [47].

\subsubsection{Floc-flotation}

As noted earlier, the principle issue related to poor floatability of fine and ultrafine particles is generally attributed to their low momentum and inertial force under conventional hydrodynamic and thermodynamic properties of flotation cells [64-65]. This leads to a low probability of $E_{c}$ and consequently, poor flotation kinetics rate constant [66-67]. Floc-flotation is a technique to aggregate the fine particles using a polymer flocculant, hydrophobic interactions and micro-organisms to obtain coarse-sized particles a.k.a. flocs to tackle those issues. There are many successfully reported achievements in a laboratory scale for coal [68], malachite [69], hematite [70], quartz and galena [71], calcite and talc [72]. However, yet only one unique industrial illustration operating since 1974 is Tilden nonmagnetic taconite concentrator located in the U.S.A. [73]. The main crucial aspect of this process is related to the type of polymer and low selectivity separation due to heterocoagulation and entrapment phenomena. More detailed information can be found elsewhere [74].

\subsection{Coarse flotation}

Few research studies showed approximately $2 \%$ improvement in the recoverability of coarse particles by distributing chemical reagents throughout the flotation circuit [75-77]. Nevertheless, coarse particle treatment by the conventional flotation machines is nearly impossible due to essential needs for a massive amount of energy for material suspension, high particle-bubble detachment probabilities, low retention time and limitations regarding the buoyancy force of the bubbles. The following section highlights two examples in terms of treating coarse fraction sizes, focusing on Flash flotation and HydroFloat ${ }^{\mathrm{TM}}$ technology.

\subsubsection{Flash flotation}

The flash flotation cell (SkimAir ${ }^{\circledR}$ Courtesy Outotec (formerly Outokumpu)) proposed in the early 1980s to flash off fast-floating liberated minerals of high value. It has been broadly used but not well understood for processing complex ores containing coarse $(-212+38 \mu \mathrm{m})$ or free gold [78]. It was designed to avoid over-grinding of the valuable dense sulfide minerals in circulating load of primary milling circuits that allows floating coarse particles with high-grades in early flotation stages [79]. Technically, flash flotation enables a concentration plant to minimize over-grinding, enhance overall recovery, increase mill throughput and improve dewatering through shrinkages filter costs and diminishes final concentrate moisture. Its feed (up to $1800 \mathrm{tph}$ ) is normally the hydrocyclone underflow with high slurry \% solids (up to $70 \%$ ), which the flash flotation tailings recirculate into the grinding unit. One important privilege, which is often overlooked, is that the SkimAir® provides a buffer for the conventional flotation circuit to produce a more stable feed when the feed grade is highly variable. Another advantage of the flash flotation is the minimal contact time of particles with reagents and almost no conditioning stage prior to the flotation. Detailed description of the process of flash flotation was presented by Newcombe et al. [80].

\subsubsection{Erize HydroFloat ${ }^{\mathrm{TM}}$ technology}

HydroFloat $^{\mathrm{TM}}$ is an aerated conical-shaped fluidized-bed (teeter-bed) separator which synergistically combines flotation with gravity/elutriation techniques enhancing the recoverability of middling $(>150 \mu \mathrm{m})$, coarse $(<2000 \mu \mathrm{m})$ and poorly liberated particles. In early 2000s, several proof-of-concept trials were carried out at laboratory and pilot scales (phosphate [81]) concerning its 
application for mostly sulfide type ores as well as potash (Canada), coal, vermiculite (U.S.A.), spodumene (Australia) and diamonds (Canada) [82]. The first full-scale industrial unit (3 $\mathrm{m}$ diameter) was commissioned at PotashCorp's Rocanville potash mill to treat approximately $125 \mathrm{t} / \mathrm{h}$ of coarse tailings. It upgraded the potash recovery from approximately 50\% to over $90 \%$ [83]. Mosaic's South Fort Meade Mine [84] and PotashCorp's Aurora beneficiation plant [85] were other successful examples. The initial sulfide mineral full-scale $(3.4 \mathrm{~m}$ diameter) installation and operation was performed on rougher flotation tailings $(-300+150 \mu \mathrm{m})$ of a copper ore at Newcrest's Cadia Valley, New South Wales, Australia in 2018.

Practically, three zones within the vessel in a top-down design are as i) free settling phase with low solids concentration, ii) fluidized bed with nearly plug-flow mixing regime, and iii) dewatering zone with higher \% solids (ca. 60\%). This design induces floatability improvements by maximizing $\mathrm{Zpb}$ and particle residence time together with a minimization of axial mixing, particle-bubble detachment rate, turbulence and froth buoyancy restrictions [86]. One crucial advantage of the Erize HydroFloat ${ }^{\mathrm{TM}}$ to the conventional cells is extremely low (1\%) necessity of mineral surface hydrophobization $(>800 \mu \mathrm{m})$ and no agitation mechanism [87]. It also leads to not only reduction of capital and operating costs but also improves sustainability, tailings management and environmental aspects [88]. Most importantly, it shows an enormous drop-off of grinding energy consumption and 20-25\% increase in mill throughput depending on the application.

\subsection{Fine and coarse flotation}

Typical overall flotation recoveries in many of mineral industries are between $80-90 \%$, and as shown in previous reports $[89,90]$ virtually in all operating concentration plants, most of the losses are in particle sizes below $20 \mu \mathrm{m}(50 \%)$ and above $150 \mu \mathrm{m}(30-40 \%)$ fractions. The third ideology is to apply advance technologies allowed to float both these extreme sizes. As an example, considering copper alone, assuming an average loss of $\sim 10 \%$, the flotation loss described could amount to at least 1.5 million tonnes per year, with a cash value of $\$ 10$ Billion. The real problem is that over $99 \%$ of what is mined in the precious metal industry is considered waste. Therefore, coarse particle flotation could allow mines to reject some waste earlier in the process before the fine flotation circuit, which might help to reduce capital and operating costs.

Each flotation cell is designed for targeting specific particle size range based on its hydrodynamic properties. It is a problem with both fine and coarse particle recovery that have been the focus of many subsequent novel cell developments. Most of these systems attempt to improve the fine or coarse particle recoveries. Therefore, it is good to have a flotation cell that floats both fine and coarse particles. The idea is that it would be part of a split circuit, presorted into coarse and fine, with technologies tailored to each. To float both size ranges, the following sections exemplify two vessels developed in bench-scale including oscillating grid cell (OGC) and reflux flotation cell (RFC).

\subsubsection{Oscillating grid flotation cell}

In the past two decades, a considerable amount of research has been undertaken in flotation, especially in the flotation cells. Research into flotation cells has focused on the development of new flotation cell technologies from a better understanding of the impact of cell hydrodynamics on the sub-processes of flotation. Several excellent studies into the effect of energy on flotation kinetics have been carried out in impeller stirred cells [91-95]. Investigations using this type of cell have a number of limitations such as the impeller influences particle suspension, bubble break-up and turbulence is highly inhomogeneous and anisotropic near the impeller [16,96]. These limitations have resulted in the development of a novel flotation cell. The OGC was initially developed for the investigation of hydrodynamic parameters like energy input on flotation performance.

Energy input in a flotation cell is an important parameter which, if optimized, can increase the flotation rate [97, 98]. Safari et al. [99] investigates the effect of energy/power input on flotation kinetics in a novel oscillating grid flotation cell in lab scale. This study clearly demonstrates that optimal energy inputs for the flotation of fine and coarse particles differ significantly. For example, the apatite flotation results indicate that flotation rate constant for the finer particles $(<38 \mu \mathrm{m})$ increases by around $200 \%$ with an increase in energy input from 0.1 to $2 \mathrm{~W} / \mathrm{kg}$. This is due to an increased bubble-particle collision/attachment. However, the flotation rate constant for the coarse particles $(-650+150 \mu \mathrm{m})$ 
decreases by over $900 \%$ over the same energy input range. This is because of improved bubble-particle detachment since the greater detaching forces lead to decreasing bubble-particle aggregate stability. The pilot OGC survey suggests that higher energy inputs are generally beneficial for the flotation of platinum ores as these consist predominantly of finer particles as observed in the flotation literature $[100,101]$.

The OGC experimental results in lab and pilot scale successfully showed that the effect of energy input on the flotation rate is strongly dependent on the particle size. The changes (increases/decreases) in the flotation rate with increasing energy input are very large for most of the conditions, indicating that this is an important parameter in flotation. The OGC results confirm the technical part behind most of the flotation cell designed so far. Safari et al. 2016b results showed why some flotation cells operate at high energy input and have high performance for fine particles; some flotation cells operate at low energy input and have high performance for coarse particles. The OGC was tested in the wide renege of particle sizes up to $650 \mu \mathrm{m}$. The survey results clearly demonstrated that the OGC had a great potential to recover fine and coarse particles by optimizing the collision efficiency, attachment efficiency and stability efficiency for each particle size rang and controlling the hydrodynamic parameters like energy input and bubble size.

\subsubsection{Reflux flotation cell (RFC)}

The RFC was initially developed for gas-liquid system and later for processing low pulp density coal slurries [102-104] showing the feasibility of extremely fast flotation [105]. This could be achieved by maximizing the kinetics of particle-bubble attachment, the bubble interfacial flux for particle extraction, and the rate of bubble-liquid segregation [106]. The maximization can be accomplished by two main features of the RFC. First inclines channels located below the main vertical section of the cell, causing to the enhancement of the bubble-liquid segregation rate, which is indeed an application of the Boycott effect [107]. The second is a multi-channelled downcomer used to deliver an extremely high flow rate into the flotation system under an excessive shear rate. A high volumetric flow rate combined with the narrow spacing within the channels generates a high shear rate, ideal for the formation of tiny bubbles and promoting collisions between the fine particles and the bubbles. Similar to the Jameson Cell, the RFC advantages a high gas hold up, leading to thin-film migration which may play a role in the particle collection [108]. Regarding the coarse size range of particles, high bubble concentrations generated by high feed fluxes at moderate gas fluxes allow for greater probabilities of particle-bubble re-attachment. Due to the excessive concentration of bubbles in the fluidized bed, any particles that detached from a bubble will immediately encounter another bubble and reattach.

\section{Conclusions}

Since the inception of froth flotation in 1905, numerous flotation machine designs have been proposed, particularly in the last 50 years. Traditionally, flotation has been performed in mechanically agitated tanks and the minerals processing industry has been particularly slow in its uptake of new cell technologies. For this purpose, the present work briefly highlighted the main concerns and advances in treating fine and coarse particles, focusing on flotation cells. A brief technical explanation, together with the historical background, was presented for each device. The primary reason for that was that the development and testing of new flotation cell designs might be costly and inherently risky to any mining company. Elaborations of mineralogical characterization techniques, which can precisely analyze the materials in extremely coarse and fine sizes seem urgent for the future of mineral processing. Also, classification equipment along with circuit designs adapted to the fine and coarse flotation require further studies in future works.

Author Contributions: Conceptualization, A.H.; validation, A.H., M.S.; investigation, A.H., M.S., D.H.H.; resources, A.H., M.S., D.H.H.; writing-original draft preparation, A.H.; writing-review and editing, A.H., M.S., D.H.H.; visualization, A.H.; supervision, A.H.. All authors have read and agreed to the published version of the manuscript.

Funding: This research received no external funding.

Conflicts of Interest: The authors declare no conflict of interest. 


\section{References}

1. Wills, B.A., Finch, J.A. 2015. Wills' Mineral processing technology: an introduction to the practical aspects of ore treatment and mineral recovery, 8th ed.; Butterworth-Heinemann: Burlington, 381-407. DOI:10.1016/B978-0-08-031159-3.50021-7

2. Gaudin, A.M., Groh, J.O. and Henderson, H.B., 1931. Effect of particle size on flotation, AIME Technical Publications, pp. 414, 3-23.

3. Mesa, D., Brito-Parada, P.R., 2018. Scale-up in froth flotation: A state-of-the-art review, Separation and Purification Technology, 210, 950-962. https://doi.org/10.1016/j.seppur.2018.08.076

4. Hassanzadeh, A., 2018. A survey on troubleshooting of closed-circuit grinding system, Canadian Metallurgical Quarterly, 57(3), 328-340. https://doi.org/10.1080/00084433.2018.1464618

5. Kingman, S.W., Rowson, N.A., 1998. Microwave treatment of minerals-A review, Minerals Engineering, 11(11), 1081-1087. https://doi.org/10.1016/S0892-6875(98)00094-6

6. Gholami, H., Rezai, B., Mehdilo, A., Hassanzadeh, A., and Yarahmadi, M.R., 2020. Effect of microwave system location on floatability of chalcopyrite and pyrite in a copper ore processing circuit, Physicochemical Problems of Mineral Processing, 56(3), 432-448. https://doi.org/10.37190/ppmp/118799

7. Batchelor, A.R., Buttress, A.J., Jones, D.A., Katrib, J., Way, D., Chenje, T., Stoll, D., Dodds, C., Kingman, S.W., 2017. Towards large scale microwave treatment of ores: Part 2-Metallurgical testing, Minerals Engineering, 111, 5-24. https://doi.org/10.1016/j.mineng.2017.05.003

8. Jameson, G.J., Emer, C., 2019. Coarse chalcopyrite recovery in a universal froth flotation machine, Minerals Engineering, 134, 118-133. https://doi.org/10.1016/j.mineng.2019.01.024

9. Azizi, D., 2018. Phosphonium/ammonium-Based ionic liquids for rare earth minerals beneficiation: Case of monazite and bastnäsite, Ph.D. Thesis, Department of Chemical Engineering, University of Laval, Quebec, Canada.

10. Trahar, W.J., Warren, L.J., 1976. The flotability of very fine particles-a review. Int. J. Miner. Process. 3(2), 103-131. https://doi.org/10.1016/0301-7516(76)90029-6

11. Trahar, W.J., 1981. A rational interpretation of the role of particle size in flotation. Int. J. Miner. Process. 8 (4), 289-327. https://doi.org/10.1016/0301-7516(81)90019-3

12. Leistner, T., Embrechts, M., Leißner, T., Chehreh Chelgani, S., Osbahr, I., Möckel, R., Peuker, U.A., Rudolph, M., 2016. A study of the reprocessing of fine and ultrafine cassiterite from gravity tailing residues by using various flotation techniques, Minerals Engineering, 96-97, 94-98. https://doi.org/10.1016/j.mineng.2016.06.020

13. Leistner, T., Peuker, U.A., Rudolph, M., 2017. How gangue particle size can affect the recovery of ultrafine and fine particles during froth flotation. Miner. Eng. 109, 1-9. https://doi.org/10.1016/j.mineng.2017.02.005

14. Hoang, D. H., Kupka, N., Peuker, N. K., Rudolph, M., 2018. Flotation study of fine grained carbonaceous sedimentary apatite ore-Challenges in process mineralogy and impact of hydrodynamics, Minerals Engineering, 121, 196-204. https://doi.org/10.1016/j.mineng.2018.03.021

15. Kouachi, S., Vaziri Hassas, B., Hassanzadeh, A., Çelik M.S., Bouhenguel, M., 2017. Effect of negative inertial forces on bubble-particle collision via implementation of Schulze collision efficiency in general flotation rate constant equation, Colloids and Surfaces A. Physicochemical and Engineering Aspects, 517(20), 72-83. https://doi.org/10.1016/j.colsurfa.2017.01.002

16. Schubert, H.J., 2008. On the optimization of hydrodynamics in fine particle flotation. Miner. Eng. 21 (1214), 930-936. https://doi.org/10.1016/j.mineng.2008.02.012

17. Safari, M., Harris, M., Deglon, D., 2017. The effect of energy input on the flotation of a platinum ore in a pilot-scale oscillating grid flotation cell. Minerals Engineering 110, 69-74. https://doi.org/10.1016/j.mineng.2017.04.012

18. Hassanzadeh, A., Firouzi, M., Albijanic, B., Celik, M.S., 2018. A review on determination of particlebubble encounter using analytical, experimental and numerical methods, Minerals Engineering, 122, 296311. https://doi.org/10.1016/j.mineng.2018.04.014

19. Orwe, D., Grano, S.R., Lauder, D.W., 1998. Increasing fine copper recovery at the OK Tedi concentrator, Papua New Guinea, Minerals Engineering, 11(2), 171-187. https://doi.org/10.1016/S0892-6875(97)00149-0

20. Small, G.L., Grano, S.R., Ralston, J., Johnson, N.W., 1997. Methods to increase fine mineral recovery in the Mount Isa Mines lead/zinc concentrator, Minerals Engineering, 10(1), 1-15. https://doi.org/10.1016/S0892-6875(96)00128-8 
21. Nicol, S.K., Engel, M.D., Teh, K.C., 1986. Fine-particle flotation in an acoustic field, International Journal of Mineral Processing, 17(1-2), 143-150. https://doi.org/10.1016/0301-7516(86)90052-9

22. Videla, A.R., Morales, R., Saint-Jean, T., Gaete, L., Vargas, Y., Miller, J.D., 2016. Ultrasound treatment on tailings to enhance copper flotation recovery, Minerals Engineering, 99, 89-95. https://doi.org/10.1016/j.mineng.2016.09.019

23. Jameson, G.J., 2010. Advances in fine and coarse particle flotation, Canadian Metallurgical Quarterly, 49(4), 325-330. https://doi.org/10.1179/cmq.2010.49.4.325

24. Govender, D., Lelinski, D., Traczyk, F., 2013. Hybrid energy flotation ${ }^{\mathrm{TM}}$ - on the optimization of fine and coarse particle kinetic in a single row, Journal of the Southern African Institute of Mining and Metallurgy,113(3), 285-296.

25. Evans, C.L., Wightman, E.M., Yuan, X., 2015. Quantifying mineral grain size distributions for process modelling using X-ray micro-tomography, Minerals Engineering, 82(15), 78-83. https://doi.org/10.1016/j.mineng.2015.03.026

26. Reyes, F., Lin, Q., Udoudo, O., Dodds, C., Lee, P.D., Neethling, S.J., 2017. Calibrated X-ray micro-tomography for mineral ore quantification, Minerals Engineering, 110, 122-130, https://doi.org/10.1016/j.mineng.2017.04.015

27. Hassanzadeh, A., Godinho, Jose R.A., Heinig, T., Möckel, R., Ebert, D., Rudolph, M., 2019a. A quantitative and comparative laboratory analyses of X-ray computed tomography and mineral liberation analyzer, Procemin Geomet, 15th International Mineral Processing Conference, Santiago, Chile, pp. 1-8.

28. Miller, J.D., Lin, C.L., 2018. X-ray tomography for mineral processing technology- 3D particle characterization from mine to mill, Minerals and Metallurgical Processing, 35(1), 1-12. https://doi.org/10.19150/mmp.8052

29. Puvvada, S., Lin, C.L., Miller, J.D., 2019. High speed X-ray computed tomography for plant-site analysis of pebble phosphate, Minerals Engineering, 130, 129-141. https://doi.org/10.1016/j.mineng.2018.08.008

30. Rezvani, A., Khalesi, M.R., Mirzaei, Z.S., Albijanic, B., 2019. Image analysis of liberation spectrum of coarse particles, Advanced Powder Technology, 30(9), 1989-1993. https://doi.org/10.1016/j.apt.2019.06.020

31. Ueda, T., Oki, T., Koyanaka, S., 2016. Statistical effect of sampling particle number on mineral liberation assessment, Minerals Engineering, 98, 204-212. https://doi.org/10.1016/j.mineng.2016.08.026

32. Evans, C.L., Napier-Munn, T.J., 2013. Estimating error in measurements of mineral grain size distribution, Minerals Engineering, 52, 198-203. https://doi.org/10.1016/j.mineng.2013.09.005

33. Kohmuench, J., Mankosa, M., Thanasekaran, H. \& Hobert, A., 2018. Improving coarse particle flotation using the HydroFloatTM (raising the trunk of the elephant curve), Minerals Engineering, 121, 137-145. https://doi.org/10.1016/j.mineng.2018.03.004

34. Safari, M., Harris, M., Deglon, D., 2016b. The effect of energy input on the flotation of a platinum ore in a pilot-scale oscillating grid flotation cell. In: Proceedings of XXVIII International Mineral Processing Congress, Quebec, pp. 27-39.

35. Tadesse, B., Albijanic, B., Makuei, F., Browner, R., 2018. Recovery of fine and ultrafine mineral particles by electroflotation-A review, Mineral Processing and Extractive Metallurgy Review, 40(2), 108-122. https://doi.org/10.1080/08827508.2018.1497627

36. Makuei, F., Tadesse, B., Albijanic, B., Browner, R., 2018. Electroflotation of ultrafine chalcopyrite particles with sodium oleate collector, Minerals Engineering, 120, 44-46. https://doi.org/10.1016/j.mineng.2018.02.012

37. Ren, L., Zeng, W., Nguyen, A.V., Ma, X., 2019. Effects of bubble size, velocity, and particle agglomeration on the electro flotation kinetics of fine cassiterite, Asia-Pacific Journal of Chemical Engineering, 1-10. https://doi.org/10.1002/apj.2333

38. Eckert, K., Schach, E., Gerbeth, G., Rudolph, M., 2019. Carrier flotation: State of the art and its potential for the separation of fine and ultrafine mineral particles, Materials Science Forum, 959, 15-133. doi:10.4028/www.scientific.net/MSF.959.125

39. Zhou, F., Wang, L., Xu, Z., Liu, Q., Chi, R., 2015. Reactive oily bubble technology for flotation of apatite, dolomite and quartz, International Journal of Mineral Processing, 134, 74-81. https://doi.org/10.1016/j.minpro.2014.11.009

40. Chen, S., Li, L., Qu, J., Liu, Q., Tang, L., Tao, X., Fan, H., 2018. Oily bubble flotation technology combining modeling and optimization of parameters for enhancement of flotation of low-flame coal, Powder Technology, 335, 171-185. https://doi.org/10.1016/j.powtec.2018.04.053 
41. Chen, S., Tao, X., Wang, S., Tang, L., Liu, Q., Li, L., 2019. Comparison of air and oily bubbles flotation kinetics of long-flame coal, Fuel, 236, 15, 636-642. https://doi.org/10.1016/j.fuel.2018.08.131

42. Farokhpay, S., Flippov, L., Fornasiero, D., 2020. Flotation of Fine Particles: A Review, Mineral Processing and Extractive Metallurgy Review, https://doi.org/10.1080/08827508.2020.1793140

43. Jameson, G.J., 2006. Method and Apparatus for Contacting Bubbles and Particles in a Flotation Separation System. International Application No.: PCT/AU2006/000123. Pub. No. WO 2006/081611.

44. Dickinson, J.E., Galvin, K.P., 2014. Fluidized bed desliming in fine particle flotation-Part I. Chemical Engineering Science, 108, 283-298. https://doi.org/10.1016/j.ces.2013.11.006

45. Bahr, A, Luedtke, $\mathrm{H}$ and Mehrhoff, F., 1982. The development and introduction of a new coal flotation cell, in Proceedings XV International Mineral Processing Congress, 17-23 October, Toronto, Canada.

46. Simonis, W, 15 October 1981- 5 May 1983. Verfahren und Flotationszelle zur Flotation von Kohle und Erz, German Patent DE3140966 A1.

47. Battersby, M.; Battersby, R. M., Flatman, S., Imhof, R., Sprenger, H., and Bragado, T. 2011. Recovery of ultrafines using Imhoflot poneumatic flotation-Two pilot plant case studies recovering nickel and zinc from tailings https://www.maelgwyn.com/wp-content/uploads/2016/04/Recovery_of_Ultra_fines.pdf

48. Young, M.F., Barnes, K.E., Anderson G.S., and Pease, J.D., 2013. Jameson Cell: the 'comeback' in base metals applications using improved design and flow sheets, in: Proceedings of the 38th Annual Canadian Mineral Processors Conference, Ottawa, Ontario, 17-19 January 2006, (Canadian Institute of Mining, Metallurgy and Petroleum), pp. 311-332.

49. Safari, M., Hoseinian, F.S., Deglon, D., Leal Filho, L.S., Souza Pinto, T.C., 2020. Investigation of the reverse flotation of iron ore in three different flotation cells: Mechanical, oscillating grid and pneumatic, Minerals Engineering, 150, 106283. https://doi.org/10.1016/j.mineng.2020.106283

50. Lima, N.P., Peres, A.E.C., Gonçalves, T.A.R. 2018. Comparative evaluation between mechanical and pneumatic cells for quartz flotation in the iron ore industry, REM, Int. Eng. J., Ouro Preto, 71(3), 437-442. http://dx.doi.org/10.1590/0370-44672016710179

51. Xstrata Technology, Jameson Cell Applications. (http://www.jamesoncell.com/EN/Applicati ons/Pages/Applications.aspx) Accessed 1 July 2013.

52. Osborne, D., Huynh, L., Kohli, I., Young M., and Mercuri, F., 2013. Two decades of Jameson Cell installations in coal, to be presented at The 17th International Coal Preparation Congress, 1-6 October, Istanbul, Turkey.

53. Araya, R., Huynh, L., Young, M., and Arburo, K., 2013. Solving challenges in copper cleaning circuits with the Jameson Cell, to be presented at: Procemin Geomet, 15-18 October, Santiago, Chile.

54. Young, M. F., Barnes, K. E., Anderson, G. S., Pease, J. D., and Zinc, X., 2006. Jameson cell: The "comeback" in base metals applications using improved design and flowsheet. In Proceedings 38th Annual Meeting of the Canadian Mineral Processors, pp. 311-322.

55. Evans, G.M., Atkinson B.W., and Jameson, G.J., 1995. The Jameson Cell, In: Flotation Science and Engineering, 331-363. http://www.jamesoncell. com/EN/Downloads/technical\%20papers/The\%20Jameson\%20Cell.pdf.

56. Fuerstenau, M.C., Jameson, G.J., and Yoon, R.H. (Eds.). 2007. Froth flotation: a century of innovation. SME.

57. Atkinson, B.W., Jameson, G.J., Nguyen, A.V., Evans, G.M., 2003. Increasing gas-liquid contacting using a confined plunging liquid jet. J. Chem. Technol. Biotechnol. 78, 269-275. https://doi.org/10.1002/jctb.768

58. Metso, 2006. Basics in Minerals Processing, Section 4 - Separations. Separations. Metso Minerals.

59. Harbort, G.J., Murphy, A.S., Budod, A., 1997. Jameson cell developments at Philex Mining Corporation. In: Proceedings of 6th Mill Operators Conference, Medang, 105-114.

60. Brown, J., Imhof, R. M., Lotzien, R., 2001. Self-aspirating Aeration Reactors for Pneumatic Flotation and other Applications, IX Balkan Mineral Processing Congress 11-13 September, Istanbul, Turkey.

61. Imhof, R.M., Battersby, M.J.G., Brown, J.V., Lotzien, R.M., Kleefeld, J., 2003. Development of Pneumatic Flotation Incorporating Centrifugal Separation. XXII International Mineral Processing Congress, 28 October, Cape Town, South Africa.

62. Battersby, M.J.G., Fletcher, M.G., Imhof, R.M., Singh, A.A., Puder, F., 2005. The Advantages of the Imhoflot G-Cell Pneumatic Flotation Process with Centrifugal Froth Removal-Two Case Studies. Randol Innovative Metallurgy Forum, 21- 24 August, Perth, Australia. 
63. Imhof, R., Battersby, M., Parra, F., and Sanchez-Pino, S., 2005. The Successful Application of Pneumatic Flotation Technology for the Removal of Silica by Reverse Flotation at the Iron Ore Pellet Plant of Compañía Minera Huasco, Chile, Centenary of Flotation Symposium, Brisbane, QLD.

64. Safari, M., Harris, M., Deglon, D., 2014. The effect of energy input on the flotation kinetics of galena in an oscillating grid flotation cell. In: Proceedings of XXVII International Mineral Processing Congress, Santiago, Chile.

65. Hassanzadeh, A., Karakas, F., 2017. Recovery improvement of coarse particles by stage addition of reagents in industrial copper flotation circuit, Journal of Dispersion Science and Technology, 38(2), 309-316. https://doi.org/10.1080/01932691.2016.1164061

66. Safari, M., Deglon, D., 2018. An attachment-detachment kinetic model for the effect of energy input on flotation. Minerals Engineering 117, 8-13. https://doi.org/10.1016/j.mineng.2017.12.006

67. Hassanzadeh, A., Azizi, A., Kouachi, S., Karimi, M., Celik, M.S., 2019b. Estimation of flotation rate constant and particle-bubble interactions considering key hydrodynamic parameters and their interrelations, Minerals Engineering, 141, 105836, https://doi.org/10.1016/j.mineng.2019.105836

68. Tian, Q., Zhang, Y., Li, G., Wang, Y., 2017. Floc-flotation of ultrafine coal slimes achieved by flotation column, Energy Sources, Part A: Recovery, Utilization, and Environmental Effects, 39(9), 899-904. https://doi.org/10.1080/15567036.2016.1273281

69. Li, Z., Rao, F., Lou, X., Song, S., López-Valdivieso, A., 2019. Floc-flotation of malachite fines with an octyl hydroxamate and kerosene mixture, Minerals, 9(5), 301, 1-13. https://doi.org/10.3390/min9050301

70. Zhong, H., Chen, W., Chen, J., 1988. Co-flocculation with polymer and surfactant. in: Proceedings of the International Symposium on the Production and Processing of Fine Particles, A.J. Plumpton (ed.), 279-288.

71. Wightman, E.M., Grano, S.R., Ralston, J., 2000. Selectivity in the polymer assisted separation of galena from quartz by flotation, Minerals Engineering, 13(8-9), 843-856. https://doi.org/10.1016/S0892-6875(00)00073-X

72. Soto, H., Barbery, G., 1988. Separation of fine particles by floc flotation. in: Proceedings of the International Symposium on the Production and Processing of Fine Particles, A.J. Plumpton (ed.), pp. 297-307.

73. Heller, K.B., Yang, J.C., 2001. Taconite Mining and Processing Industry Profile, Draft Report, U.S. Environmental Protection Agency, U.S.A. https://www3.epa.gov/ttnecas1/regdata/IPs/Taconite_IP.pdf

74. Song, S., Lopez-Valdivieso, A., Reyes-Bahena, J.L., 1999. Hydrophobic flocculation applied to fine mineral and coal processing, XXIII Convencion AIMMGM, 20-23 October, Acapulco, Gro., Mexico, pp. 1-20.

75. Bazin, C., Proulx, M., 2001. Distribution of reagents down a flotation bank to improve the recovery of coarse particles, International Journal of Mineral Processing, 61(1), 1-12. https://doi.org/10.1016/S0301-7516(00)00022-3

76. Banerjee, P.K., Gupta, A.K., Mukherjee, A.K., Das, P., Singh, N.P., Singh, R.S., 2007. Optimization of reagents distribution down a coal flotation bank to improve the recovery of coarser particles, Coal Preparation, 27(1-3), 39-56. https://doi.org/10.1080/07349340701249711

77. Hassanzadeh, A., Kouachi, S., Hasanzadeh, M., Çelik M.S. 2017. A new insight to the role of bubble properties on inertial effect in particle-bubble interaction, Journal of Dispersion Science and Technology, 38(07), 953-960. https://doi.org/10.1080/12269328.2017.1392900

78. McGrath, T.D.H., Eksteen, J.J., Heath, J., 2015. The behaviour of free gold particles in a simulated flash flotation environment, The Journal of The Southern African Institute of Mining and Metallurgy, 115, 103-112.

79. Bustamante-Rúa, M.O., Najanjo-Gómez, D.M., Daza-Aragón, A.J., Bustamante-Baena, P. and Osorio-Botero, J.D., 2018. Flash flotation of free coarse gold using dithiophosphate and dithiocarbamate as a replacement for traditional amalgamation, Dyna, 85(205), 163-170. http://dx.doi.org/10.15446/dyna.v85n205.69882.

80. Newcombe, B., Bradshaw, D., Wightman, E., 2012. Flash flotation. . . and the plight of the coarse particle, Minerals Engineering, 34, 1-10. https://doi.org/10.1016/j.mineng.2012.03.023

81. Kohmuench, J.N., Luttrell, G.H., 2001. Coarse particle concentration using the HydroFloat Separator, Minerals \& Metallurgical Processing, 18(2), 61-67.

82. Awatey, B., Thanasekaran, H., Kohmuench, J.N., Skinner, W. \& Zanin, M., 2013. Optimization of operating parameter for coarse sphalerite flotation in the HydroFloat fluidised-bed separator, Minerals Engineering, 50-51, 99-105. https://doi.org/10.1016/j.mineng.2013.06.015 
83. Kohmuench, J.N., Thanasekaran, H., 2013. Fluidized-bed flotation: applications from industrial minerals to sulfides. In: Proceedings, Flotation 2013, Cape Town, South Africa, November 18-21.

84. Kohmuench, J.N., Mankosa, M.J., Kennedy, D.G., Yasalonis, J.L., Taylor, G.B., Luttrell, G.H., 2007. Implementation of the HydroFloatTM technology at the south fort Meade mine, Mining, Metallurgy \& Exploration, 24(4), 264-270. https://doi.org/10.1007/BF03403375

85. Piegols, G., DePlato, D., Kohmuench, J.N., Yan, E.S., 2015. Application of Classification and Fluidized-Bed Flotation at PCS Aurora. In: Beneficiation of Phosphates, Proceedings VII, Engineering Foundation Conference on Beneficiation of Phosphates VI, March 29-April 3, 2015, Melbourne, Australia, pp. 14.

86. Tariqul Islam, Md., Nguyen, A.N., 2019. A numerical study with experimental validation of liquid-assisted fluidization of particle suspensions in a HydroFloat cell, Minerals Engineering, 134, 176-192. https://doi.org/10.1016/j.mineng.2019.02.005

87. Miller, J.D., Lin, C.L., Wang, Y., Mankosa, M.J., Kohmuench, J.N., Luttrell, G.H., 2016. The significance of exposed grain surface area in coarse particle flotation of low grade gold ore with the HydroFloatTM technology, In: Proceedings, XXVIII International Mineral Processing Congress, September 11-15, Québec City Convention Center, Québec, Canada, Paper 455, pp 10.

88. Kohmuench, J.N., Mankosa, M.J., Yan, E.S., Wyslouzil, H., Christodoulou, L., 2010. Advances in coarse particle flotation-industrial minerals. In: Proceedings, 25th International Mineral Processing Congress, 2010. The Australasian Institute of Mining and Metallurgy, Victoria, pp. 2065-2076.

89. Bulatovic, S.M., Wyslouzil, D.M., and Kant, C., 1998. Operating practices in the beneficiation of major porphyry copper/molybdenum plants from Chile: Innovated technology and opportunities, a review, Miner. Eng., 11, 313-331. https://doi.org/10.1016/S0892-6875(98)00011-9

90. Barkhordari, H.R., Jorjani, E., Eslami, A., and Noaparast, M., 2009. Occurrence mechanism of silicate and aluminosilicate minerals in Sarcheshmeh copper flotation concentrate, Int. J. Min. Metal. Mat., 16(5), 494-499. https://doi.org/10.1016/S1674-4799(09)60086-8

91. Pyke, B., Fornasiero, D., Ralston, J., 2003. Particle-bubble heterocoagulation under turbulent conditions. J. Colloid Interface Sci. 265, 141-151. https://doi.org/10.1016/S0021-9797(03)00345-X

92. Newell, R., Grano, S., 2006. Hydrodynamics and scale up in Rushton turbine flotation cells: Part 2 Flotation scale-up for laboratory and pilot cells. Int. J. Miner. Process. 81, 65-78. https://doi.org/10.1016/j.minpro.2006.07.002

93. Hoseinian, F.S., Rezai, B., Kowsari, E., Safari, M., 2019b. Effect of impeller speed on the Ni(II) ion flotation, Geosystem Engineering 22(3), 161-168. https://doi.org/10.1080/12269328.2018.1520651

94. Hoseinian, F.S., Rezai, B., Safari, M., D.A. Deglon, Kowsari, E., 2019a. Effect of hydrodynamic parameters on nickel removal rate from wastewater by ion flotation. Journal of Environmental Management 244, 408414. https://doi.org/10.1016/j.jenvman.2019.05.067

95. Hoseinian, F.S., Rezai, B., Kowsari, E., Safari, M., 2020. A hybrid neural network/genetic algorithm to predict Zn(II) removal by ion flotation, Separation Science and Technology (Philadelphia) 55(6), 1197-1206. https://doi.org/10.1080/01496395.2019.1582543

96. Koh, P.T.L., Schwarz, M.P., 2003. CFD modelling of bubble-particle collision rates and efficiencies in a flotation cell. Miner. Eng. 16, 1055-1059. https://doi.org/10.1016/j.mineng.2003.05.005

97. Testa, F., Safari, M., Deglon, D., Filho, L.L., 2017. Influence of agitation intensity on flotation rate of apatite particles, REM - International Engineering Journal R. Esc. Minas, 70(4), 491-495. https://doi.org/10.1590/0370-44672017700010

98. Safari, M., Hoseinian, F.S., Deglon, D., Leal Filho, L.S., Souza Pinto, T.C., 2019. Investigation of the reverse flotation of hematite in three different types of laboratory flotation cells, In: Proceedings of XXIX International Mineral Processing Congress, IMPC 2018, Russia, pp. 1376-1383.

99. Safari, M., Harris, M., Deglon, D., Leal Filho, L., Testa, F., 2016a. The effect of energy input on flotation kinetics. International Journal of Mineral Processing 156, 108-115. https://doi.org/10.1016/j.minpro.2016.05.008

100. Deglon, D.A., 1998. A hydrodynamic investigation of fine particle flotation in a batch flotation cell, Ph.D. Thesis, Department of Chemical Engineering, University of Cape Town, South Africa.

101. Deglon, D.A., 2005. The effect of agitation on the flotation of platinum ores, Minerals Engineering, 18(8), 839-844. https://doi.org/10.1016/j.mineng.2005.01.024

102. Dickinson, J.E., Galvin, K.P., 2014. Fluidized bed desliming in fine particle flotation -part I. Chem. Eng. Sci. 108, 283-298. https://doi.org/10.1016/j.ces.2013.11.006 
103. Galvin, K.P., Dickinson, J.E., 2014. Fluidized bed desliming in fine particle flotation-Part II. Chem. Eng. Sci. 108, 294. https://doi.org/10.1016/j.ces.2013.11.027

104. Galvin, K.P., Harvey, N.G., Dickinson, J.E., 2014. Fluidized bed desliming in fine particle flotation-Part III. Miner. Eng. 66-68, 94-101. https://doi.org/10.1016/j.mineng.2014.02.008

105. Jiang, K., Dickinson, J.E., Galvin, K.P., 2019. The kinetics of fast flotation using the reflux flotation cell, Chem. Eng. Sci. 196, 463-477. https://doi.org/10.1016/j.ces.2018.11.012

106. Dickinson, J.E., Jiang, K., Galvin, K.P., 2015. Fast flotation of coal at low pulp density using the reflux flotation cell. Chem. Eng. Res. Des. 101, 74-81. https://doi.org/10.1016/j.cherd.2015.04.006

107. Boycott, A.E., 1920. Sedimentation of blood corpuscles. Nature 104, 532.

108. Harbort, G.J., Manlapig, E.V., Debono, S.K., 2002. Particle collection within the Jameson cell downcomer. Trans. Inst. Min. Metall. Sect. C-Miner. Process. Extract. Metall. 111, C1-C10. https://doi.org/10.1179/mpm.2002.111.1.1

(C) 2020 by the authors. Submitted for possible open access publication under the terms and conditions of the Creative Commons Attribution (CC BY) license (http://creativecommons.org/licenses/by/4.0/). 